\title{
Improving Germination Rate of Coastal Glehnia by Cold Stratification and Pericarp Removal
}

\author{
Moon-Sun Yeom ${ }^{1,2}$, Thi Kim Loan Nguyen ${ }^{1,2}$, Ju-Sung Cho ${ }^{1,2}$ and Myung-Min Oh ${ }^{1,2, *}$ \\ 1 Division of Animal, Horticultural, and Food Sciences, Chungbuk National University, Cheongju 28644, Korea; \\ msy1023@cbnu.ac.kr (M.-S.Y.); kimloanmt@gmail.com (T.K.L.N.); jsc@cbnu.ac.kr (J.-S.C.) \\ 2 Brain Korea 21 Center for Bio-Health Industry, Chungbuk National University, Cheongju 28644, Korea \\ * Correspondence: moh@cbnu.ac.kr; Tel.: +82-43-261-2530
}

check for updates

Citation: Yeom, M.-S.; Nguyen, T.K.L.; Cho, J.-S.; Oh, M.-M. Improving Germination Rate of Coastal Glehnia by Cold Stratification and Pericarp Removal. Agronomy 2021, 11, 944. https://doi.org/ 10.3390/agronomy11050944

Academic Editor: Matteo Caser

Received: 30 March 2021

Accepted: 4 May 2021

Published: 10 May 2021

Publisher's Note: MDPI stays neutral with regard to jurisdictional claims in published maps and institutional affiliations.

Copyright: (C) 2021 by the authors. Licensee MDPI, Basel, Switzerland. This article is an open access article distributed under the terms and conditions of the Creative Commons Attribution (CC BY) license (https:// creativecommons.org/licenses/by/ $4.0 /)$.

\begin{abstract}
The medicinal plant, coastal glehnia (Glehnia littoralis F. Schmidt ex Miq.), belongs to the Apiaceae, which is known to exhibit morpho-physiological seed dormancy (MPD). In this study, we aimed to determine the dormancy type of this plant, along with the conditions for breaking dormancy, and how to increase its germination rate for mass production. Initially, the seeds of coastal glehnia had undeveloped embryos, which gradually developed following cold $\left(5^{\circ} \mathrm{C}\right)$ stratification over eight weeks. The embryo to seed (E:S) ratio increased to $66.7 \%$, confirming that the seeds had the MPD type. Coastal glehnia seeds with pericarp did not show inhibited water uptake, and the germination inhibitory chemicals were not detected. However, removal of the pericarp improved the final germination percentage, germination speed, and $\mathrm{T}_{50}$ of coastal glehnia seeds compared with those of seeds with pericarp at $20^{\circ} \mathrm{C}$, which showed the highest value compared with other temperature treatments. Thus, cold stratification at $5{ }^{\circ} \mathrm{C}$ for eight weeks and removing the pericarp of germinating seeds maintained at $20{ }^{\circ} \mathrm{C}$ is efficient ways to break dormancy and improve the germination rate for the mass production of coastal glehnia.
\end{abstract}

Keywords: coastal glehnia; medicinal plant; morpho-physiological seed dormancy; seed dormancy; seed germination

\section{Introduction}

Glehnia littoralis F. Schmidt ex Miq. (English name: coastal glehnia, Korean name: Gaet-bang-pung) is a perennial herb belonging to the Apiaceae that is distributed all across the coast and sand dunes of the South Korea, with flowering in early summer. The umbel inflorescences of coastal glehnia have oval-shaped fruits that are as dense as the number of flowers. After the fruit is ripe, the seeds are densely formed and seed pericarp becomes lignification [1]. The leaves of coastal glehnia have been consumed as a leafy vegetable and in oriental medicine, it is used with bang-pung, a famous medicinal vegetable used for the treatment of stroke. The root of the coastal glehnia is called Beisha ginseng (buksa-sam) and sea sand ginseng (haesa-sam) in herbal medicine, where it is used as a crude drug. Um et al. [2] identified furocoumarin groups such as imperatorin, psoralen, xanthotoxin, and bergapten, in the extracts of the shoots and roots of coastal glehnia, which have anti-oxidative, anti-inflammatory, anti-HIV, and anti-rheumatic properties. Therefore, coastal glehnia is perceived as a functional vegetable and is regarded as a plant with high commercial value for use in health-promoting food products, cosmetics, or plant-derived pharmaceuticals. However, damaged ecosystems and climate change have resulted in a population decline of coastal glehnia in the wild. In Korea, it is currently belongs to rare plant while, according to the standard of the International Union for Conservation of Nature, the government classified it into the category of least concern species [3]. In addition, owing to its limited cultivation conditions, environments, and short leaf production periods, large-scale production of coastal glehnia for plant raw materials of high commercial value is limited. 
The establishment of whole production processes, such as propagation, transplanting (seedling), and vegetative and reproductive growth processes is required for the mass production of the medicinal plants in controlled environments, such as greenhouses and vertical farms. In the propagation step, which is the first step, the seed germination is generally used as the primary propagation method because it is easy to produce a large number of seedlings for mass production [4].

The efficiency of seed germination is determined by three factors: the environment, seed viability, and seed dormancy. Unlike cultivated species, most medicinal plants are wild species that undergo dormancy and, therefore, require specific environmental conditions for germination. Among several types of dormancy, most Apiaceae exhibit morphological physiological dormancy (MPD). The umbel is characterized by seeds with different seed shattering orders, embryo development, and seed maturity in each inflorescence, which is why they exhibit immature embryos and non-uniform germination [5,6]. Pre-chilling $\left(4{ }^{\circ} \mathrm{C}\right)$ for seven days and subsequent treatment at $20{ }^{\circ} \mathrm{C}$ was the most effective method to break dormancy and increase the germination rate of Peucedanum japonicum Thunb., a species within the Apiaceae, compared to maintaining seeds under a constant $20{ }^{\circ} \mathrm{C}$ treatment [5]. In addition, a $72 \%$ of germination percentage was recorded in European Chaerophyllum temulum seeds kept at $10^{\circ} \mathrm{C}$ for two weeks after $5^{\circ} \mathrm{C}$ stratification for eight weeks, while treatment at $30{ }^{\circ} \mathrm{C}$ for two weeks after eight weeks of $5{ }^{\circ} \mathrm{C}$ stratification showed germination rates of only approximately 20\% [7]. Chinese Glehnia littoralis seed was completely broken dormancy by $4{ }^{\circ} \mathrm{C}$ of stratification for 120 days [8]. These results suggest that specific temperature conditions may be required for breaking dormancy and improving the germination of Apiaceae seeds.

In this study, we aimed to obtain high-quality seedlings of coastal glehnia by identifying the dormancy type and how to break it, as well as determining the most suitable germination conditions.

\section{Materials and Methods}

2.1. Seeds

Coastal glehnia seeds were provided by the Bonghwa Herbal Crop Research Institute in the Republic of Korea $\left(36^{\circ} \mathrm{N}, 129^{\circ} \mathrm{E}\right)$. The average water content of dry seeds was $11.4 \%$ and the weight of 100 seeds was approximately $1.43 \mathrm{~g}$. Dried seeds were sealed in a plastic bag at $4{ }^{\circ} \mathrm{C}$ until use.

\subsection{Imbibition Test}

Ten plastic dishes $(9 \times 9 \times 2.4 \mathrm{~cm})$ were filled with $30 \mathrm{~mL}$ of distilled water, and 10 seeds with pericarps $(n=10)$ were immersed in each dish. The immersed seeds with pericarps were taken out, removed water on the surface with paper towels, and then weighed every $0.5 \mathrm{~h}$ for $12.5 \mathrm{~h}$ (25 times) at $22{ }^{\circ} \mathrm{C}$ using an electronic scale (Si-234, Denver Instrument, Denver, CO, USA).

\subsection{Inhibitory Effect of Pericarps on Germination}

Dried seeds with pericarp, soaked seeds with pericarp in running water for 1 and 3 days and moist cold stratification-treated (8 weeks) seeds with pericarp were prepared and each seed group were divided into three sub-groups: seeds without pericarps, seeds with pericarps, and pericarps for the experimental materials (Supplementary Figure S1). All the materials were freeze-dried for approximately $73 \mathrm{~h}$ to remove moisture (Alpha 1-4 LSC plus; Martin Christ Co., Osterode, Germany). Subsequently, all the samples were milled to make a powder (Tube Mill control, IKA, Wilmington, NC, USA). To prepare the extract, $0.4 \mathrm{~g}$ of powder and $20 \mathrm{~mL}$ of distilled water were mixed, incubated in a water bath (MaXturdy-30, Daihan Scientific, Wonju, Korea) at $50{ }^{\circ} \mathrm{C}$ for $48 \mathrm{~h}$, and filtered through a 0.22- $\mu \mathrm{m}$ syringe filter (Smartpor-II, Woongki, Seoul, Korea).

Lettuce seeds (Lactuca sativa L. 'Cheongchima'; Asia Seed Co., Seoul, Korea), with an official germination rate of $75 \%$, were sown in a Petri dish $(150 \times 20 \mathrm{~mm})$ on filter paper 
to test the inhibitory effect of the solutions extracted from seeds with pericarp, without pericarp, and the pericarp alone. Three Petri dishes were used for each treatment. The extract $(5 \mathrm{~mL})$ was supplied daily for 7 days, and the germination of lettuce seeds was observed in a growth chamber set as follows: air temperature of $20^{\circ} \mathrm{C}$, relative humidity of $60 \%, 12 \mathrm{~h}$ light period, and fluorescent lamp, photosynthetic photon flux density (PPFD) of $150 \mu \mathrm{mol} \cdot \mathrm{m}^{-2} \cdot \mathrm{s}^{-1}$. The control was supplied with the same amount of distilled water daily instead of the extract. Lettuce seeds radicles with lengths more than $2 \mathrm{~mm}$ were considered germinated and the number of germinated seeds was counted every day.

\subsection{Effect of Cold and/or Warm Stratification on Embryo Development}

Coastal glehnia seeds were soaked in running tap water for 3 days and sterilized with 500 ppm of benomyl (Dongbu Farm, Seoul, Korea) for $6 \mathrm{~h}$. After this, four replicates of 25 seeds were placed on wet filter paper in Petri dishes and incubated in growth chambers (DS-51GLP, Dasol Scientific Co., Ltd., Hwaseong, Korea). These chambers were set at $5{ }^{\circ} \mathrm{C}$ and $25{ }^{\circ} \mathrm{C}$ for 11 weeks under the following light environment: fluorescent lamp, $30 \mu \mathrm{mol} \cdot \mathrm{m}^{-2} \cdot \mathrm{s}^{-1} \mathrm{PPFD}$, and light period of $16 \mathrm{~h} / 8 \mathrm{~h}$ (light/dark). Additionally, some seeds treated at $5{ }^{\circ} \mathrm{C}$ were moved to $25^{\circ} \mathrm{C}$ after 5 weeks of incubation. To monitor the embryo development of seeds according to the stratification temperature, the ratio of embryo length to seed length (E:S ratio) was measured every week for 8 weeks using a stereoscopic microscope (SMZ-U, Nikon, Tokyo, Japan) $(n=10)$ with software (Version 4.5, Leica Application Suite). Germination of the cold $\left(5^{\circ} \mathrm{C}\right)$ and/or warm $\left(25^{\circ} \mathrm{C}\right)$ stratification treatments was performed when the radicle of the seeds was above $2 \mathrm{~mm}$ in length in the remaining 20 seeds, after measuring the E:S ratio for 8 weeks.

\subsection{Effect of Temperatures on Germination in Relation to the Pericarp}

The seeds treated with cold stratification for 8 weeks were divided into two groups, seeds with pericarps and seeds without pericarps. These were used for germination experiments under different temperature treatments.

Both seed groups were incubated in growth chambers (VS-1203PF-L, Vision Scientific Co. Ltd., Daejeon, Korea) set at five different air temperatures $\left(5^{\circ} \mathrm{C}, 10{ }^{\circ} \mathrm{C}, 15{ }^{\circ} \mathrm{C}\right.$, $20^{\circ} \mathrm{C}$, and $25^{\circ} \mathrm{C}$ ) for 31 days under the following light conditions: fluorescence lamp, $30 \mu \mathrm{mol} \cdot \mathrm{m}^{-2} \cdot \mathrm{s}^{-1} \mathrm{PPFD}$, and a $16 \mathrm{~h}$ light period. The germination rate was measured every 2 days for 31 days. The average germination rate was confirmed from 50 seeds for each temperature treatment, and the mean germination time (MGT) was calculated using the formula of Ellis and Roberts [9]:

$$
\mathrm{MGT}=\sum(t \times n) / \sum n
$$

where $t$ is the time in days from day 1 to the final day of the germination test, and $n$ is the total number of germinated seeds on day $t$.

Time to $50 \%$ germination $\left(\mathrm{T}_{50}\right)$ was calculated using the formula suggested by Coolbear et al. [10]:

$$
\mathrm{T}_{50}=t_{i}+\left[\frac{\frac{(n+1)}{2}-n_{i}}{n_{j}-n_{i}}\right]\left(t_{j}-t_{i}\right)
$$

where $n$ is the final number of germinated seeds, and $n_{i}$ and $n_{j}$ are the total number of germinated seeds by adjacent counts at time $t_{i}$ and $t_{j}$, where $n_{i}<(n+1)<n_{j}$. Four replicates of 50 seeds were placed in Petri dishes for each treatment $(n=4)$.

\subsection{Data Analysis}

Analysis of variance was performed using the Statistical Analysis System (SAS 9.4; SAS Institute, Cary, NC, USA) and Duncan's multiple range test was used to compare the means. Differences were considered significant at $p<0.05$. 


\section{Results}

\subsection{Imbibition Test and Inhibitory Effect of the Pericarp on Germination}

An imbibition test was conducted to determine if the seeds of the coastal glehnia had physical dormancy type. Seeds covered with pericarps absorbed water immediately after immersion and became saturated after $6.6 \mathrm{~h}$ (Figure 1).

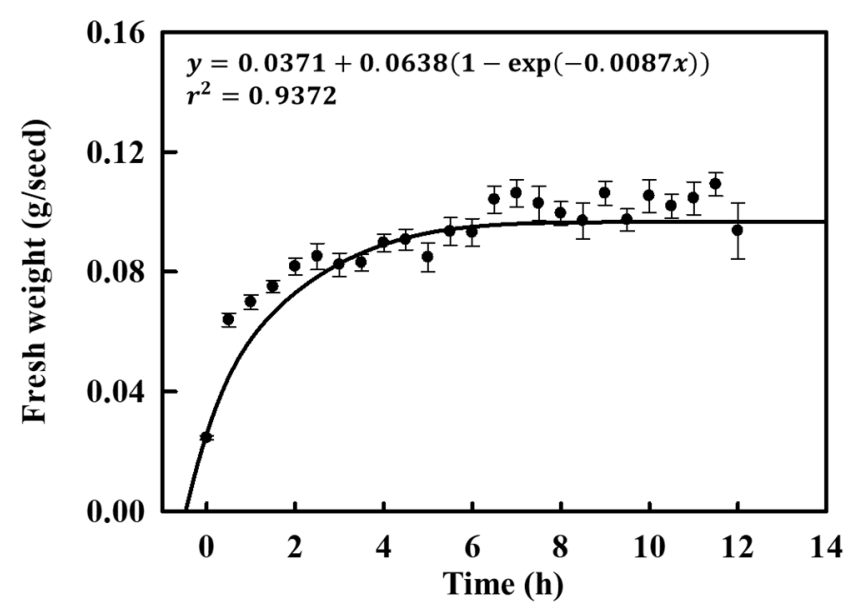

Figure 1. Imbibition curve of coastal glehnia seeds for $12.5 \mathrm{~h}$. The vertical bars indicate standard errors $(n=10)$.

To identify the inhibitory effect of the pericarp, lettuce seeds were germinated in the extract from dry seeds, soaked in running water for one and three days, and subjected to cold stratification, which were further divided into seeds with pericarps, seeds without pericarps, and pericarps. The germination percentage of the control was $83.3 \% \pm 1.2 \%$ and that of the other extracts showed an average of $83.6 \% \pm 1.2 \%$, which was not significantly different (Figure 2).

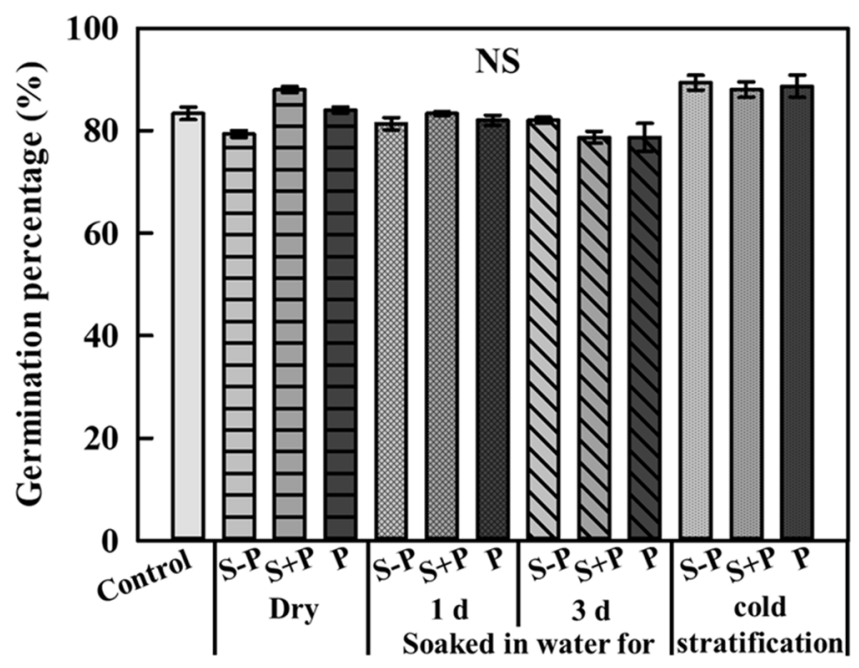

Figure 2. Germination percentage of lettuce seeds treated with extracts from dry seeds, soaked in water for one and three days, and subjected to cold stratification. The treatments were further divided into seeds without pericarps $(S-P)$, seeds with pericarps $(S+P)$, and pericarps only $(P)$ after seven days $(n=3)$. NS means no significant difference.

\subsection{Cold and/or Warm Stratification for Breaking Dormancy}

The sectioned coastal glehnia seeds showed an undeveloped embryo (Figure 3A). The length of embryos and seeds were $1.04 \pm 0.04$ (mean $\pm \mathrm{SE}$ ) $\mathrm{mm}$ and $6.55 \pm 0.28 \mathrm{~mm}$, respectively, and the E:S ratio was approximately 0.15 (Figure 3B). In the first four weeks, 
warm $\left(25^{\circ} \mathrm{C}\right)$ stratification stimulated the embryo development of coastal glehnia seeds more strongly than cold $\left(5^{\circ} \mathrm{C}\right)$ stratification, and the level of development stagnated after this point. However, cold $\left(5^{\circ} \mathrm{C}\right)$ stratification allowed embryo development to continue, leading to a higher development in five weeks than that after warm $\left(25^{\circ} \mathrm{C}\right)$ stratification. The temperature change from cold $\left(5{ }^{\circ} \mathrm{C}\right)$ to warm $\left(25^{\circ} \mathrm{C}\right)$ stratification at five weeks had no effect on embryo development. Final germination rates of cold $\left(5^{\circ} \mathrm{C}\right)$ and /or warm $\left(25^{\circ} \mathrm{C}\right)$ stratification treatments were significantly different among the treatments (Figure 4). After 11 weeks of treatment, cold $\left(5^{\circ} \mathrm{C}\right)$ stratification induced $10 \%$ germination and temperature change $\left(5{ }^{\circ} \mathrm{C}\right.$ to $\left.25^{\circ} \mathrm{C}\right)$ induced $2 \%$ germination, whereas warm $\left(25^{\circ} \mathrm{C}\right)$ stratification resulted in no germination.
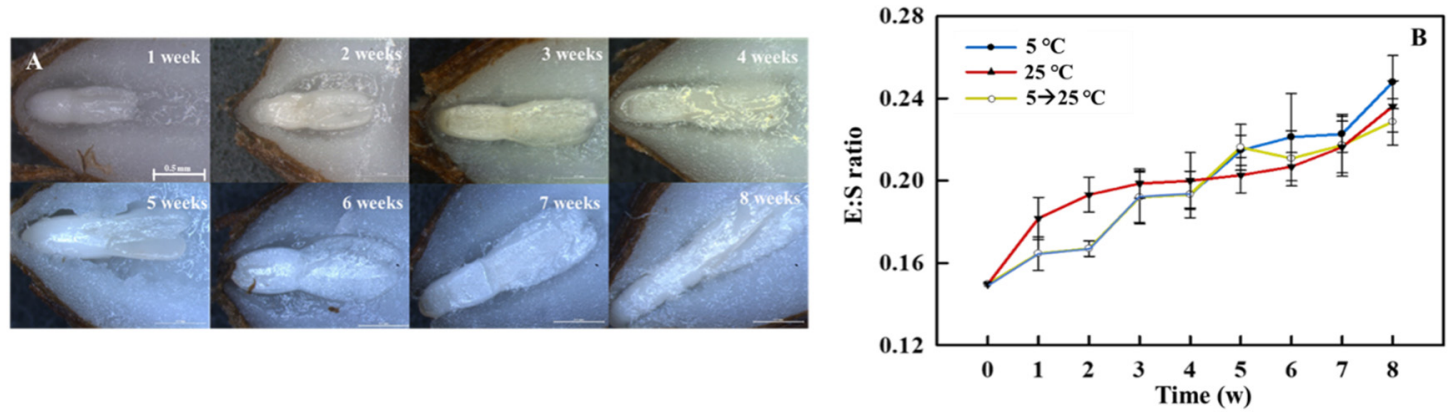

Figure 3. (A) Microscopic images of cold $\left(5^{\circ} \mathrm{C}\right)$ stratification-treated embryo development of a coastal glehnia seed over eight weeks. Reference bars represent $0.5 \mathrm{~mm}$. (B) Ratio of embryo to seed (E:S ratio) of coastal glehnia seeds for eight weeks of cold $\left(5^{\circ} \mathrm{C}\right)$ and warm $\left(25^{\circ} \mathrm{C}\right)$ stratification treatment, and cold $\left(5^{\circ} \mathrm{C}\right)$ stratification for five weeks before being moved to warm $\left(25^{\circ} \mathrm{C}\right)$ stratification treatment for three weeks $\left(5 \rightarrow 25^{\circ} \mathrm{C}\right)$. The vertical bars indicate standard errors $(n=10)$.

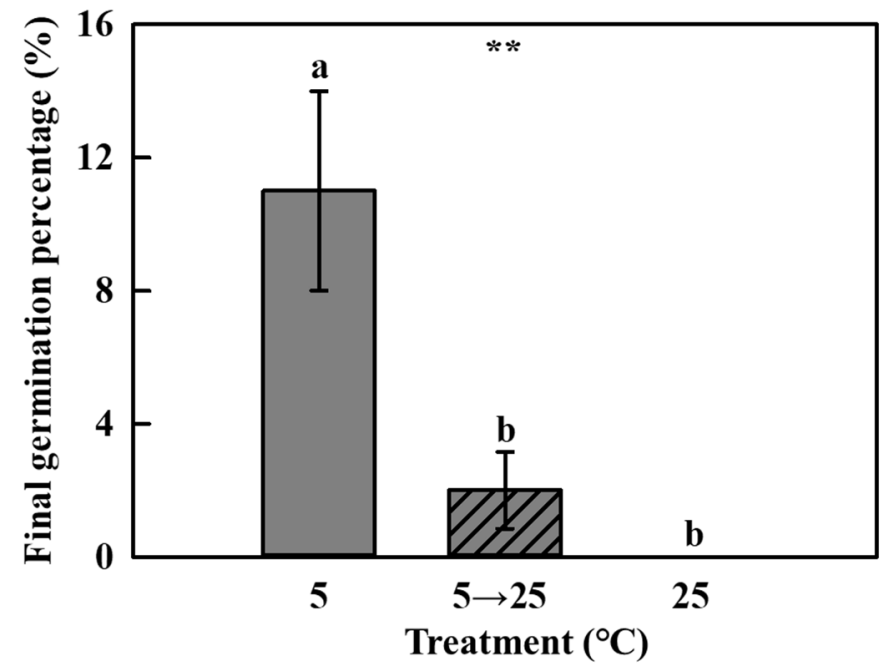

Figure 4. Final germination percentage of coastal glehnia seeds after 11 weeks of cold $\left(5{ }^{\circ} \mathrm{C}\right)$ or warm $\left(25^{\circ} \mathrm{C}\right)$ stratification treatment, and cold stratification for five weeks before being moved to warm stratification treatment $\left(5 \rightarrow 25^{\circ} \mathrm{C}\right)$. The vertical bars indicate standard errors. Different letters showed significant differences. ${ }^{* *}$ indicates significance at $p<0.01(n=4)$.

\subsection{Temperature Requirements for Germination with or without Pericarp}

This experiment was performed to select the ideal germination temperature conditions for breaking the dormancy of coastal glehnia seeds and to determine the effect of the pericarp on germination. The coastal glehnia seeds showed significant differences in germination rate, depending on the presence of the pericarp and the five different temperature treatments (Figure 5). The average germination percentage of all temperature treatments at 31 days was approximately $56 \%$ for seeds without pericarps and $26 \%$ for seeds with pericarps. The seeds with pericarps comprised $35.5 \% \pm 4.3 \%$ of the final ger- 
mination percentage at $15^{\circ} \mathrm{C}$, which was the highest value, and was significantly higher than $5{ }^{\circ} \mathrm{C}$ and $25^{\circ} \mathrm{C}$ treatments (Figure 5A). In the case of seeds without pericarp, there was no significant difference in the final germination percentage at $10^{\circ} \mathrm{C}, 15^{\circ} \mathrm{C}$, and $20^{\circ} \mathrm{C}$ treatments; however, stratification at $15{ }^{\circ} \mathrm{C}$ recorded the highest rate $(68 \% \pm 2.6 \%)$ and was significantly higher than that at $25^{\circ} \mathrm{C}$ and $5^{\circ} \mathrm{C}$ (Figure 5B).

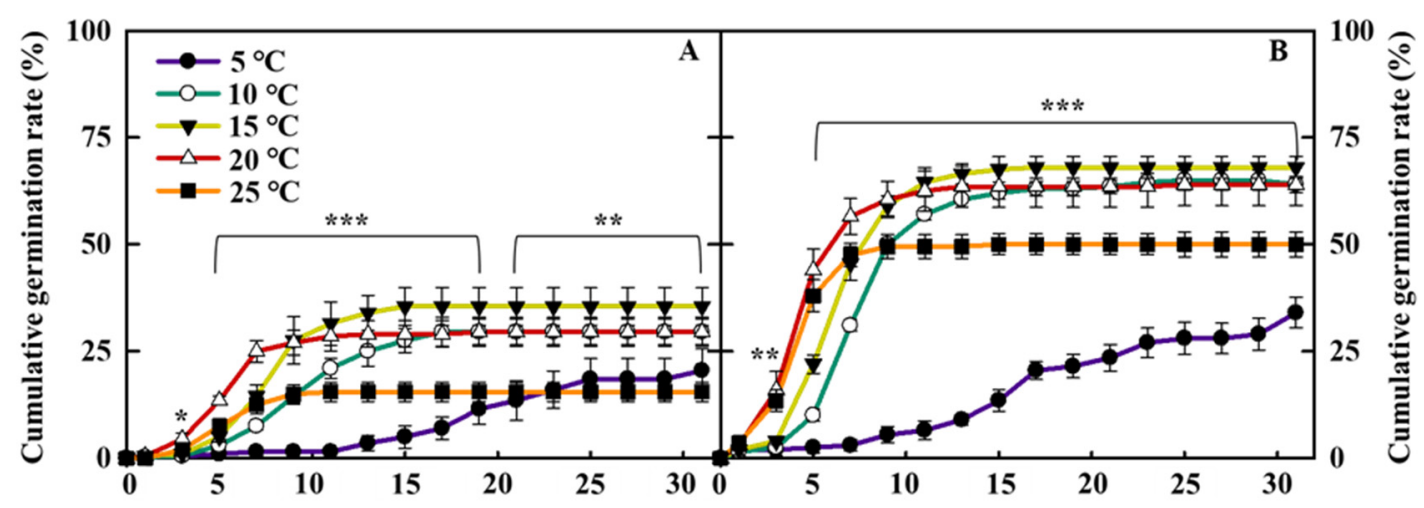

Figure 5. Cumulative germination rate of cold stratification treated coastal glehnia seeds with pericarps (A) and without pericarps (B) at five different air temperatures $\left(5,10,15,20\right.$, and $\left.25^{\circ} \mathrm{C}\right)$ for 31 days. The vertical bars indicate standard errors. ${ }^{*}, * *$, and ${ }^{* * *}$ indicate significance at $p<0.05,0.01$, and 0.001 , respectively $(n=4)$.

The mean germination time (MGT) in seeds with and without pericarps was 19.9 days and 17.4 days, respectively, under the $5{ }^{\circ} \mathrm{C}$ treatment, which was significantly longer than that in the other four temperature treatments (Figure 6). Conversely, treatment at $20^{\circ} \mathrm{C}$ and $25{ }^{\circ} \mathrm{C}$ resulted in MGT values of 6.3 days and 6.1 days in seeds with pericarp, and 5.4 days and 5.2 days in seeds without pericarps, respectively. This showed a significantly lower MGT than what was obtained with the other temperature treatments.

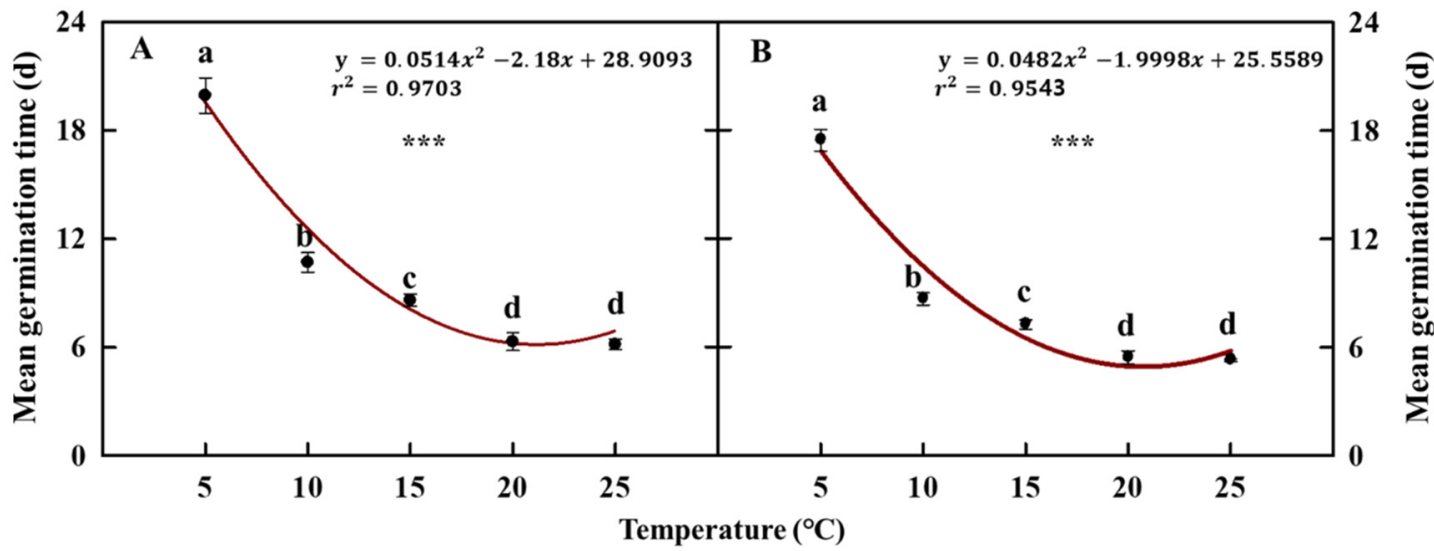

Figure 6. Mean germination time (MGT) of cold stratification treated coastal glehnia seeds with pericarps (A) and without pericarps $(\mathbf{B})$ at five different air temperatures $\left(5,10,15,20\right.$, and $\left.25^{\circ} \mathrm{C}\right)$ for 31 days. The vertical bars indicate standard errors. Different letters showed significant differences. ${ }^{* * *}$ indicates significance at $p<0.001(n=4)$.

Likewise, under the $5{ }^{\circ} \mathrm{C}$ treatment, the time taken to obtain $50 \%$ seed germination $\left(\mathrm{T}_{50}\right)$ showed the significantly higher values of 19.5 and 17.2 days, in seeds with and without the pericarp, respectively, requiring more time for germination than the other treatments (Figure 7). Meanwhile, in the $20^{\circ} \mathrm{C}$ and $25^{\circ} \mathrm{C}$ treatments, it was confirmed that the time required for the germination of $50 \%$ of seeds was significantly shorter than that for the other treatments. These were 5.1 days and 5.5 days for seeds with pericarp and 4.2 days and 4.0 days for those without pericarp. 


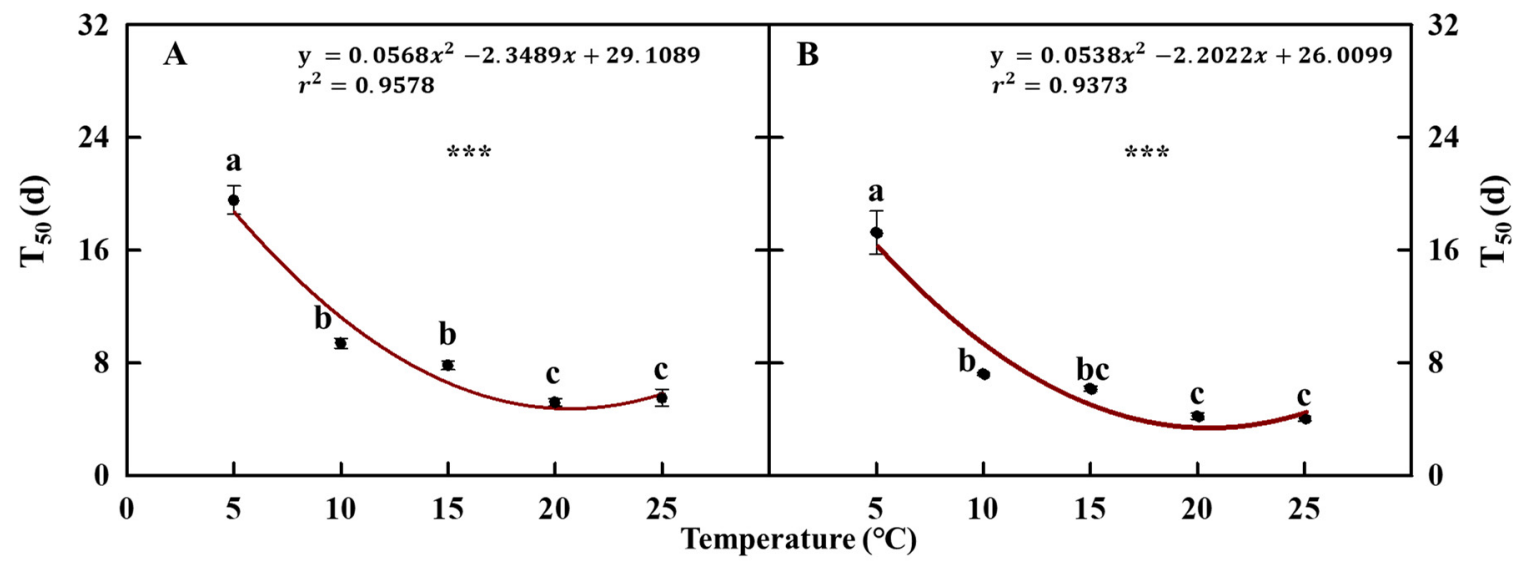

Figure 7. Time taken to achieve $50 \%\left(\mathrm{~T}_{50}\right)$ of germination of cold stratification-treated coastal glehnia seeds with pericarps (A) and without pericarps (B) at five different air temperatures $\left(5,10,15,20\right.$, and $\left.25^{\circ} \mathrm{C}\right)$ for 31 days. The vertical bars indicate standard errors. Different letters showed significant differences. ${ }^{* * *}$ indicates significance at $p<0.001(n=4)$.

\section{Discussion}

\subsection{Imbibition Test and the Germination Inhibitory Effect of the Pericarp}

The pericarp of seeds is used as an ecological adaptation strategy to germinate seeds at the opportune time in arid and semi-arid environments. In this way, the survival rate of seedlings is increased as the pericarp protects seeds from harsh environments for germination, inhibits water absorption, and contains chemical inhibitors that induce physical and chemical dormancy [11-13]. Hedysarum scoparium, which is native arid environments, delays water absorption for $6 \mathrm{~h}$ in seeds with pericarps compared to seeds without pericarps [12]. However, the pericarp of coastal glehnia seeds did not affect water absorption, and seed water saturation occurred within $6.6 \mathrm{~h}$ in the imbibition test, which was measured every $30 \mathrm{~min}$ under laboratory conditions. This result indicates that the pericarp of coastal glehnia seeds does not induce physical dormancy (PY) because of its impermeability.

Germination inhibitory substances in the pericarp can be identified by biological assays of germination inhibitors used in experiments [14]. In this study, we used lettuce seeds for the biological assay and identified germination rates of over $79 \%$ in all treatments and control. Therefore, it was confirmed that the pericarp of coastal glehnia seeds did not contain significant amounts of chemical substances to inhibit germination. This implies that the dormancy of coastal glehnia seeds was not caused by any chemical inhibitors in the pericarps. Taken together, these results show that coastal glehnia seeds did not exhibit PY or pericarp-imposed dormancy. They also revealed that soaking seeds in running water may not be a critical process in breaking seed dormancy.

\subsection{Cold and/or Warm Stratification for Breaking Dormancy}

The Apiaceae has an indeterminate inflorescence flower structure, meaning that the embryo development of the seeds is different in the same plant and even in every inflorescence. For this reason, the time required for germination is long and the germination rate is low. Moreover, it is difficult to obtain uniform seedlings [15,16]. Coastal glehnia seeds have different maturities, sizes, and weights in each inflorescence, which is common in the Apiaceae. The average E:S ratio of coastal glehnia seeds was 0.15 , and stratification treatment promoted embryo development of the seeds, regardless of the temperature. However, treatment under $5{ }^{\circ} \mathrm{C}$ cold stratification for eight weeks induced a $66.7 \%$ increase in E:S ratio from 0.15 to 0.25 , eventually leading to germination (but only at a rate of $10 \%$; Figures 3 and 4). In the field, the embryo of coastal glehnia seeds develops in winter, and radicle emergence occurs in the following spring. For this type of seed, cold stratification treatment may mimic winter conditions, which can promote the immature embryos of seeds and induce dormancy breaking. Coastal glehnia seeds have immature embryos 
and require cold conditions for development, suggesting that they exhibit morphological physiological dormancy (MPD). In the Apiaceae, MPD-type seeds of Aegopodium podagraria showed embryo development and germinated only at $5^{\circ} \mathrm{C}$ stratification in temperaturecontrolled incubators [17]. In addition, MPD-type seeds of Eremurus anisopterus had an increased E:S ratio from 0.73 to 0.87 after 16 weeks of cold treatment and $91 \%$ of the final germination percentage at 36 weeks after treatment [18].

\subsection{Temperature Requirements for Germination with or without the Pericarp}

After seeds absorb water, the most important environmental factor for germination is temperature. Temperature determines the germination capacity and germination rate of seeds and can cause additional dormancy or break dormancy [19]. Seeds that have absorbed water digest the stored substances using various enzymes, converting them into small molecules so that they can easily diffuse and mobilize to areas which require materials and energy for germination [20].

The final germination percentages of seeds with and without pericarp were $20.5 \%$ and $34 \%$, respectively, at $5{ }^{\circ} \mathrm{C}$; which was low regardless of the presence or absence of the pericarp. It is believed that the decreased activity of enzymes for decomposing endosperm storage limits the germination of coastal glehnia seeds [21]. At $15^{\circ} \mathrm{C}$, both seeds with pericarp (35.5\%) and without pericarp $(68 \%)$ showed the highest final germination percentages, but the MGT and $\mathrm{T}_{50}$ values were significantly higher than those at $20{ }^{\circ} \mathrm{C}$ and $25^{\circ} \mathrm{C}$, regardless of the presence of the pericarp. In other words, the $15^{\circ} \mathrm{C}$ treatment took longer to achieve uniform seedlings. Meanwhile, at $20{ }^{\circ} \mathrm{C}$, the final germination percentage was not significantly different from that at $15^{\circ} \mathrm{C}$, but the MGT and $\mathrm{T}_{50}$ values were significantly lower than those at $15^{\circ} \mathrm{C}$. Therefore, $20^{\circ} \mathrm{C}$ is an appropriate temperature condition for the germination of coastal glehnia seeds after breaking dormancy, and can even be effective for uniform seed germination. In general, the appropriate temperature conditions for germination are related to the climatic conditions in the country of origin, and they can be suitable for seedling development and establishment [22]. The average temperature from April to July in Uljin, where coastal glehnia naturally performs vegetative growth, is $18.7^{\circ} \mathrm{C}$, which is similar to the effective germination temperature of $20^{\circ} \mathrm{C}$ in this experiment.

The pericarp tissues of the Apiaceae are mainly composed of lignin, cellulose, and hemicellulose. These plants have tough tissues and can control the germination of seeds by covering the seeds to protect them from unfavorable environments [23]. Immediately after radicle germination, the seeds require significant energy consumption to penetrate the weakest part of the pericarp, which may delay seedling development. In this study, the pericarp of the coastal glehnia did not cause seed dormancy, but instead delayed germination. The pericarp of the seeds distributed in the coastal area, where continuous moisture absorption is difficult, may control germination by retaining water. In addition, the stress that occurs during the process of penetrating into the pericarp of coastal glehnia, due to the development of the radicle, can act as a survival strategy that increases the survival rate of seedlings by improving environmental tolerance and adaptability to harsh environments after germination. However, the seed pericarp can also be an obstacle in controlled environment agriculture, which requires mass and uniform seedling production. In this respect, the removal of the pericarp using the seed polisher machine would be a solution for commercializing the mass production of coastal glehnia.

\section{Conclusions}

In this study, we aimed to gather information to better establish a mass production system for coastal glehnia, a medicinal plant, through environmental control in greenhouses or vertical farms. To this end, we identified the dormancy type of coastal glehnia seeds and how to break this dormancy. We also determined the ideal germination conditions for these seeds. Coastal glehnia seeds have a MPD type dormancy, which can be broken by cold stratification treatment for at least eight weeks at $5^{\circ} \mathrm{C}$, followed by germination 
at $20{ }^{\circ} \mathrm{C}$ to induce an improved germination rate. Thus, the establishment of the coastal glehnia seed germination methods can be provided as a production method for farmers who cultivate the open field. These methods will also be useful for mass production and year-round production of coastal glehnia in plant production facilities.

Supplementary Materials: The following are available online at https: / www.mdpi.com/article / 10.3390 /agronomy11050944/s1, Figure S1: Seeds without pericarps, seed with pericarps, and only pericarps of coastal glehnia.

Author Contributions: Conceptualization, M.-S.Y. and M.-M.O.; methodology, M.-S.Y., J.-S.C. and M.-M.O.; software, M.-S.Y. and T.K.L.N.; validation, M.-S.Y., T.K.L.N., J.-S.C. and M.-M.O.; formal analysis, M.-S.Y.; investigation, M.-S.Y. and T.K.L.N.; resources, M.-M.O.; data curation, M.-S.Y.; writing-original draft preparation, M.-S.Y.; writing-review and editing, J.-S.C. and M.-M.O.; visualization, M.-S.Y.; supervision, M.-M.O.; project administration, M.-S.Y. and M.-M.O.; funding acquisition, M.-M.O. All authors have read and agreed to the published version of the manuscript.

Funding: This research was funded by the "Cooperative Research Program for Agriculture Science \& Technology Development (Project No. PJ01385201)” Rural Development Administration, Republic of Korea.

Institutional Review Board Statement: Not applicable.

Informed Consent Statement: Not applicable.

Data Availability Statement: All the data is available in the paper.

Conflicts of Interest: The authors declare no conflict of interest.

\section{References}

1. Kim, E.K. Halophytes of Korea, 1st ed.; Econature: Seoul, Korea, 2013; pp. 194-197.

2. Um, Y.R.; Lee, J.I.; Lee, J.H.; Kim, H.J.; Yea, S.S.; Seo, Y.W. Chemical constituents of the halophyte Glehnia littoralis. J. Korean Chem. Soc. 2010, 54, 701-706. [CrossRef]

3. Korea Biodiversity Information System (KBIS). Available online: http:/ / www.nature.go.kr/ (accessed on 15 March 2021).

4. Hartmann, H.T.; Kester, D.E.; Davies, J.F.T.; Geneve, R.L. Hartmann E Kester's Plant Propagation: Principles and Practices, 8th ed.; Pearson Education Limited: Hoboken, NJ, USA, 2014; pp. 113-116.

5. Lee, H.S.; Lee, J.W.; Kim, S.J.; Lee, J.H.; Sung, J.S.; Kang, M.J.; Ma, K.H. Effects of temperature, light and chemical reagent on dormancy breaking and seed germination of three species in Apiaceae. J. Korean Soc. Int. Agric. 2014, 26, 519-525. [CrossRef]

6. Lee, E.S.; An, T.J.; Kim, Y.I.; Park, W.T.; Kim, Y.G.; Chang, J.K. Seed ripening characteristics by inflorescence according to days after flowering in Angelica acutiloba (Siebold \& Zucc.) Kitagawa. Korean J. Plant Res. 2020, 33, 86-92.

7. Vandelook, F.; Bolle, N.; Van Assche, J.A. Seed dormancy and germination of the European Chaerophyllum temulum (Apiaceae), a member of a trans-Atlantic genus. Ann. Bot. 2007, 100, 233-239. [CrossRef] [PubMed]

8. Shao, C.; Wang, G.; Ding, X.; Yang, C.; Yan, M. Physiological and biochemical characteristics of cold stratification to overcome morphophysiological dormancy in Glehnia littoralis seed. Seed Sci. Technol. 2021, 49, 19-24.

9. Ellis, R.H.; Roberts, E.H. Improved equations for the prediction of seed longevity. Ann. Bot. 1980, 45, 13-30. [CrossRef]

10. Coolbear, P.; Francis, A.; Grierson, D. The effect of low temperature pre-sowing treatment on the germination performance and membrane integrity of artificially aged tomato seeds. J. Exp. Bot. 1984, 35, 1609-1617. [CrossRef]

11. Sari, A.O.; Oguz, B.; Bilgic, A. Breaking seed dormancy of laurel (Laurus nobilis L.). New Forests 2006, 31, 403-408. [CrossRef]

12. Hu, X.W.; Wang, Y.R.; Wu, Y.P. Effects of the pericarp on imbibition, seed germination, and seedling establishment in seeds of Hedysarum scoparium Fisch. et Mey. Ecol. Res. 2008, 24, 559-564. [CrossRef]

13. Baskin, C.C.; Baskin, J. Seeds, 2nd ed.; Academic Press: San Diego, CA, USA, 2014; pp. 72-77.

14. Fujii, Y.; Parvez, S.S.; Parvez, M.M.; Ohmae, Y.; Iida, O. Screening of 239 medicinal plant species for allelopathic activity using the sandwich method. Weed Biol. Manag. 2003, 3, 233-241. [CrossRef]

15. Dean, B.B.; Noland, T.; Maguire, J.D. Correlation of low seed quality with growing environment of carrot. HortScience 1989, 24, 247-249.

16. Moon, J.O.; Park, K.W.; Kang, H.M. Effects of treatment of light, temperature and priming on germination of Angelica acutiloba Kitagawa seeds. Hortic. Sci. Technol. 2003, 21, 434-439.

17. Vandelook, F.; Bolle, N.; Van Assche, J.A. Morphological and physiological dormancy in seeds of Aegopodium podagraria (Apiaceae) broken successively during cold stratification. Seed Sci. Res. 2009, 19, 115-123. [CrossRef]

18. Mamut, J.; Tan, D.Y.; Baskin, C.C.; Baskin, J.M. Intermediate complex morphophysiological dormancy in seeds of the cold desert sand dune geophyte Eremurus anisopterus (Xanthorrhoeaceae; Liliaceae s.1.). Ann. Bot. 2014, 114, 991-999. [CrossRef] [PubMed] 
19. Bewley, J.D.; Bradford, K.J.; Hillhorst, H.W.M.; Nonogaki, H. Seeds: Physiology of Development, Germination and Dormancy, 3rd ed.; Springer: Berlin/Heidelberg, Germany, 2013; pp. 311-312.

20. Moon, W.; Yu, D.J. Physiology of Cultivated Plants, 3rd ed.; Know press: Seoul, Korea, 2015; pp. $266-274$.

21. Bewley, J.D.; Black, M. Physiology and Biochemistry of Seeds in Relation to Germination, 1st ed.; Springer: Berlin/Heidelberg, Germany, 1982; pp. 297-307.

22. Probert, R.J. The role of temperature in the regulation of seed dormancy and germination. In Seed the Ecology of Regeneration in Plant Communities, 2nd ed.; Fenner, M., Ed.; Cabi Publishing: New York, NY, USA, 2000; pp. 261-270.

23. Habibi, Y.; Heux, L.; Mahrouz, M.; Vignon, M.R. Morphological and structural study of seed pericarp of Opuntia ficus-indica prickly pear fruits. Carbohydr. Polym. 2008, 72, 102-112. [CrossRef] 